\title{
Viral Communities of Shark Bay Modern Stromatolites
}

\author{
Richard Allen White III,2,3,4,5, Hon L. Wong ${ }^{4,6}$, Rendy Ruvindy ${ }^{4,6}$, Brett A. Neilan ${ }^{4,6}$ and \\ Brendan P. Burns ${ }^{4,6 *}$ \\ ${ }^{1}$ Institute of Biological Chemistry, Washington State University, Pullman, WA, United States, ${ }^{2}$ Crop and Soil Sciences, \\ Washington State University, Pullman, WA, United States, ${ }^{3}$ Plant Pathology, Washington State University, Pullman, WA, \\ United States, ${ }^{4}$ Australian Centre for Astrobiology, University of New South Wales, Sydney, NSW, Australia, ${ }^{5}$ RAW Molecular \\ Systems (RMS) LLC, Spokane, WA, United States, ${ }^{6}$ School of Biotechnology and Biomolecular Science, University of \\ New South Wales, Sydney, NSW, Australia
}

Single stranded DNA viruses have been previously shown to populate the oceans on a global scale, and are endemic in microbialites of both marine and freshwater systems. We undertook for the first time direct viral metagenomic shotgun sequencing to explore the diversity of viruses in the modern stromatolites of Shark Bay Australia. The data indicate that Shark Bay marine stromatolites have similar diversity of ssDNA viruses to that of Highbourne Cay, Bahamas. ssDNA viruses in cluster uniquely in Shark Bay and Highbourne Cay, potentially due to enrichment by phi29-mediated amplification bias. Further, pyrosequencing data was assembled from the Shark Bay systems into two putative viral genomes that are related to Genomoviridae family of ssDNA viruses. In addition, the cellular fraction was shown to be enriched for antiviral defense genes including CRISPR-Cas, BREX (bacteriophage exclusion), and DISARM (defense island system associated with restriction-modification), a potentially novel finding for these systems. This is the first evidence for viruses in the Shark Bay stromatolites, and these viruses may play key roles in modulating microbial diversity as well as potentially impacting ecosystem function through infection and the recycling of key nutrients.

Keywords: ssDNA viruses, viral defense, CRISPR-Cas, BREX, Shark Bay, stromatolites, viral metagenomics

\section{INTRODUCTION}

Viruses represent the largest genetic repository and most abundant host-associated replicating entities on the planet (Breitbart and Rohwer, 2005; Suttle, 2005, 2007). Viruses infect all living organisms and viruses have been proposed to influence critical biochemical processes, such as photosynthesis and carbon fixation (Suttle, 2005, 2007; Thompson et al., 2011). Environmental viral metagenomics (i.e., viromics) has revealed that $>90 \%$ of genes are hypothetical or uncharacterized (Angly et al., 2006), and thus it is likely that new genes will be found amongst viruses. A recent metagenomic study that exhaustively analyzed 3,042 geographically diverse samples revealed extensive global viral diversity, including recovering $\sim 125,000$ partial DNA viral genomes, and yet more than $75 \%$ of the viral genes were hypothetical or uncharacterized (PaezEspino et al., 2016). This indicated that more than two-thirds of all viral protein coding genes have currently no known function. The field of viromics currently has many tools for obtaining genomes and benchmarking (Roux et al., 2017), quantification of dsDNA and ssDNA viruses (Roux et al., 2016), and is truly coming of age (Sullivan et al., 2017). Viruses play a key role in carbon cycling representing $>20 \%$ of all microbial biomass lysed daily in marine ecosystems 
(Suttle, 2007). This massive genetic repository of billions of uncharacterized and hypothetical genes is formidable, however, linking viruses to ecosystems could provide greater understanding of the role of viruses in global processes.

Previous viral metagenomic studies have suggested that linking various viral genotypes to certain environments to establish viral biogeography is challenging. Often the same viral genotype is found in a variety of ecosystems suggesting that viruses have a cosmopolitan distribution (Breitbart and Rohwer, 2005). A viral metagenomic study that contrasted this concept of cosmopolitan viral biogeography suggested that viral ecotypes do exist in nature (Desnues et al., 2008). It was found that single-stranded DNA microphages from Highbourne Cay stromatolites were endemic and these specific viruses were not found among any other cross-examined ecosystem, including marine, freshwater, terrestrial or metazoan-associated systems. However, this is the only study to date that exists for viral communities among modern microbialites (Desnues et al., 2008).

However, the use of multiple-displacement amplification (MDA) using phi29 polymerase has been well documented to bias amplification toward ssDNA viruses over dsDNA viruses (Kim and Bae, 2011). This can make viral biogeography analyses challenging as absolute quantification of viral ecotypes can be difficult due to this amplification bias, however, general diversity is still maintained (Kim and Bae, 2011). Due to strand displacement events, the phi29 polymerase appears to amplify circular DNA more efficiently than linear DNA in diverse nucleic acid pools found in viromes in environmental ecosystems (Kim and Bae, 2011). A recent study found on average that phi29 polymerase amplification bias toward ssDNA viruses was systematically over-represented $>10$-fold, and that this method on average captured 2-15 times more ssDNA viral genomes (Roux et al., 2016). However, many studies have used this method (phi29 mediated amplification) to selectively enrich and amplify ssDNA viruses and measure diversity in ocean water (Rosario et al., 2009a), reclaimed water (Rosario et al., 2009b), human feces (Reyes et al., 2010), and modern microbialites (Desnues et al., 2008).

Modern stromatolites are analogs to early microbial ecosystems, some dating back 3.5 billion years (Gya) (Dupraz and Visscher, 2005; Van Kranendonk et al., 2008; Dupraz et al., 2009). However, modern marine stromatolites are less extensively distributed compared to the early Earth (Van Kranendonk et al., 2008), with Shark Bay and Highbourne Cay harboring some of the most well-studied examples. Several studies have characterized the extensive microbial diversity in the Shark Bay ecosystem, including novel bacterial, archaeal, and eukaryotic groups (Burns et al., 2004; Goh et al., 2009; Edgecomb et al., 2014; Wong et al., 2015, 2017; Ruvindy et al., 2016; Suosaari et al., 2016). To date no study has delineated the viral contribution to overall biological diversity of the modern stromatolites of Shark Bay, and the aim here was thus to describe the diversity of viruses in Shark Bay stromatolites for the first time. This was achieved by analyzing the purified viral fraction (e.g., free viral particles) and cellular fraction (i.e., lysogenic/prophage or viruses in active infection amongst the cellular fraction) via filtration then direct shotgun sequencing and comparing to similar microbialite viromes prepared in the same manner (e.g., Highbourne Cay, Pozas Azules II and Rios Mesquites).

\section{MATERIALS AND METHODS}

\section{Sampling, Viral Metagenomic Library Construction, and Sequencing}

Columnar stromatolites were collected and sampled in 2009 from the south-eastern shore of Hamelin Pool, Shark Bay, Western Australia (26 $\left.25 \mathrm{~S}, 114^{\circ} 130 \mathrm{E}\right)$ as described previously (Burns et al., 2004; Ruvindy et al., 2016). Samples were collected at low tide using a sterile spatula. At the time of sampling, the temperature was recorded as $27.4^{\circ} \mathrm{C}$, salinity 68 (Practical Salinity Unit; PSU) and $\mathrm{pH}$ 7.9. Samples were placed in sterile specimen containers and stored at $4^{\circ} \mathrm{C}$ during transportation for $\sim 30 \mathrm{~min}$. DNA was extracted immediately upon sample return. Viral and cellular fraction metagenomes were purified, amplified with MDA via phi29 polymerase, and sequenced as described (Desnues et al., 2008). Briefly, $\sim 5 \mathrm{~g}$ of Shark Bay stromatolite material was shaken in $30 \mathrm{ml}$ of SM buffer $(0.1 \mathrm{M}$ $\mathrm{NaCl}, 1 \mathrm{mM} \mathrm{MgSO} 4,0.2 \mathrm{M}$ Tris $\mathrm{pH} 7.5,0.01 \%$ gelatin within $0.02 \mu \mathrm{m}$ filtered seawater for $1 \mathrm{~h}$ (Desnues et al., 2008). Filtration was used to separate the microbial fraction from the viral fraction using $0.22 \mu \mathrm{m}$ filters. The Shark Bay cellular fraction (i.e., microbial cellular fraction) was the stromatolite and cellular material collected on the $0.22 \mu \mathrm{m}$ filter, and the flow through was considered the viral particle fraction. The viral particle fraction was then further purified using cesium chloride density gradient centrifugation (Thurber et al., 2009), and checked for bacterial and eukaryotic cells using SYBR straining and epifluorescence microscopy (Thurber et al., 2009). Both the viral and microbial fraction DNA were isolated using formamide/CTAB extraction (Sambrook et al., 1989), then amplified with phi29-based MDA via GenomiPhi (GE Healthcare) following the manufacturer's recommendations. Subsequently, $\sim 10 \mu \mathrm{g}$ DNA was sequenced using 454 pyrosequencing (Margulies et al., 2005).

\section{Quality Control of Sequencing Data and Assembly}

The 454-pyrosequencing data (raw SFF files) were converted to FASTQ format and binned by molecular barcode (multiplex identifier). Data were examined for quality using FastQC ${ }^{1}$. Shark Bay metagenome barcodes were removed by Tagcleaner (Schmieder et al., 2010), sequences were trimmed for low quality ( $\left.>\mathrm{Q}_{25}\right)$, poly-A/T/N tails, de-duplicated (100\% extract match), and ambiguous bases/sequences ( $>100 \mathrm{bp}$ ) and sequences with complexity $(>70)$ on entropy scales removed by PRINSEQ (Schmieder and Edwards, 2011). High quality reads for the Shark Bay Virome (not cellular fraction) were assembled in order to find putative viral genomes and increase contig size using Ray DeNovo Assembler using (Kmer size = 31) (Boisvert et al., 2010, 2012, Table 1).

\footnotetext{
${ }^{1}$ www.bioinformatics.babraham.ac.uk/projects/fastqc/
} 


\section{Annotation and Analysis}

High quality reads and viral-assembled contigs were loaded onto MetaVir ${ }^{2}$ and updated using MetaVir2 to analyze the Shark Bay Virome and Shark Bay Cellular fraction (Roux et al., 2011, 2014). Basic local alignment search tool (BLAST) based comparison in MetaVir was implemented (e-value $\leq 10^{-3}, 10^{-5}, 10^{-7}$ ) against the NCBI refseq database (updated refseq 2017-01-11), and normalized to genome length using the built-in Genomerelative Abundance and Average Size (GAAS) normalization tool (Angly et al., 2006; Roux et al., 2011). KO EC numbers (directly KEGG mapped), refseq and SEED subsystem annotations, were analyzed by MG-RAST. MG-RAST was used for the main taxonomic and functional annotation (Meyer et al., 2008) of both microbial and viral fractions, and MetaVir2 employed for virome analysis. To search for antiviral gene homologs amongst the viral and cellular fraction, high quality reads were translated to predicted proteins using prodigal (Hyatt et al., 2010), and were annotated against the PFAM/TIGRFAM and KEGG using

${ }^{2}$ http://metavir-meb.univ-bpclermont.fr/
BLAST, InterProScan 5, and GhostKoala (Jones et al., 2014; Kanehisa et al., 2016).

Principal coordinate analyse (PCA) analysis was undertaken using GAAS outputs from MetaVir2 and R libraries Ecodist (dissimilarity-based functions for ecological analysis), pvclust (hierarchical clustering with $P$-values via Multiscale Bootstrap Resampling), ward clustering, and Bray-Curtis distance metrics at a 1000 replicates against the viromes and microbial fractions for Highboune Cay, Pozas Azules II, Ríos Mesquites microbialites (Desnues et al., 2008).

\section{Phylogenetic Analysis}

Marker gene identification was completed using reference trees provided by MetaVir2 for major capsid protein for Microviridae (VP1), auxiliary metabolic gene (AMG) phoH which is widespread in phage genomes but whose function remains unknown (Goldsmith et al., 2011), and replicationassociated protein (Rep) found in ssDNA viruses.

Of the VP1 contigs, those with sequence length lower than 160 were deleted. Reference viral replication proteins

TABLE 1 | Metagenomic statistics including read analysis, assembly stats, and annotations for MetaVir2 and MG-RAST.

\begin{tabular}{|c|c|c|c|c|}
\hline Reads & Viral fraction & Cellular fraction & Assembly & Viral fraction \\
\hline Raw data & & & Contigs $>100 \mathrm{bp}$ & \\
\hline Number & 92298 & 73371 & Number & 504 \\
\hline Total length (bp) & 39623558 & 31023655 & Total length (bp) & 149063 \\
\hline Average (bp) & 429 & 423 & Average (bp) & 295 \\
\hline \multirow[t]{2}{*}{$\mathrm{GC} \%$} & $48 \%$ & $44 \%$ & N50 (bp) & 353 \\
\hline & & & Median (bp) & 172 \\
\hline After QC data & & & Largest (bp) & 4099 \\
\hline Number & 62294 & 59805 & Contigs $>500$ bp & \\
\hline Artificial duplicate reads & 23699 & 8842 & Number & 49 \\
\hline Total length (bp) & 28413896 & 26636206 & Total length (bp) & 57537 \\
\hline Average (bp) & 456 & 445 & Average (bp) & 1174 \\
\hline \multirow[t]{2}{*}{ GC\% } & $47 \%$ & $44 \%$ & N50 (bp) & 1473 \\
\hline & & & Median (bp) & 924 \\
\hline MG-RAST predictions & & & Largest (bp) & 4099 \\
\hline Predicted protein features & 39127 & 50281 & & \\
\hline Predicted rRNA features & 3321 & 3746 & & Cellular fraction \\
\hline Identified protein features & 2452 & 23704 & Contigs $>100 \mathrm{bp}$ & \\
\hline Identified rRNA features & 0 & 64 & Number & $\mathrm{N} / \mathrm{A}$ \\
\hline Identified functional categories & 2033 & 21025 & Total length (bp) & $\mathrm{N} / \mathrm{A}$ \\
\hline Failed QC (duplicates/length) & $30,004(32.51 \%)$ & 13,566 (18.49\%) & Average (bp) & $\mathrm{N} / \mathrm{A}$ \\
\hline Unknown & $1,000(1.08 \%)$ & $197(0.27 \%)$ & N50 (bp) & $\mathrm{N} / \mathrm{A}$ \\
\hline Predicted feature & 61,294 (66.41\%) & 59,608 (81.24\%) & Median (bp) & $\mathrm{N} / \mathrm{A}$ \\
\hline Unknown protein & 30,514 (49.78\%) & 20,191 (33.87\%) & Largest (bp) & $\mathrm{N} / \mathrm{A}$ \\
\hline Annotated protein & $30,780(50.22 \%)$ & $38,473(64.54 \%)$ & Contigs $>500$ bp & \\
\hline \multirow[t]{2}{*}{ Ribosomal RNA } & $0(0.00 \%)$ & $944(1.58 \%)$ & Number & $\mathrm{N} / \mathrm{A}$ \\
\hline & & & Total length (bp) & $\mathrm{N} / \mathrm{A}$ \\
\hline MetaVir2 predictions* & & & Average (bp) & $\mathrm{N} / \mathrm{A}$ \\
\hline 50 on score & $6.55 \%$ & $10.62 \%$ & N50 (bp) & $\mathrm{N} / \mathrm{A}$ \\
\hline E-value $\left(10^{-3}\right)+$ GAAS & $9.04 \%$ & $15.50 \%$ & Median (bp) & $\mathrm{N} / \mathrm{A}$ \\
\hline E-value $\left(10^{-5}\right)+$ GAAS & $7.42 \%$ & $12.57 \%$ & Largest (bp) & $\mathrm{N} / \mathrm{A}$ \\
\hline E-value $\left(10^{-7}\right)+$ GAAS & $6.53 \%$ & $10.54 \%$ & & \\
\hline
\end{tabular}

*Represents a significant viral hit. GAAS is genome length normalization. 
(phoH, VP1, Rep) and proteins obtained from the Shark Bay virome (viral fraction) were aligned using MUSCLE (Edgar, 2004), and alignment gaps were removed with $\mathrm{UGENE}^{3}$ (Okonechnikov et al., 2012). Maximum likelihood phylogenetic trees were constructed using IQ-TREE v. 1.6.1 with a total of 1000 bootstrap replicates, and visualized with iTOL (Letunic and Bork, 2016; Hoang et al., 2017).

${ }^{3}$ http://ugene.net/

\section{Data Availability}

The assembled data Shark Bay virome and microbial fraction have been deposited in MetaVir and are available under project names "Shark Bay Virome" and "Shark Bay Microbes," and additionally in MG-RAST as "Shark Bay Virome," and "Shark Bay Microbes." All codes and scripts can be found on github.com/raw937. Both pre-assembled and assembled reads have been deposited in the Sequence Read Archive (SRA) under accession numbers SRR7160500 and SRZ187061, and BioProject
A

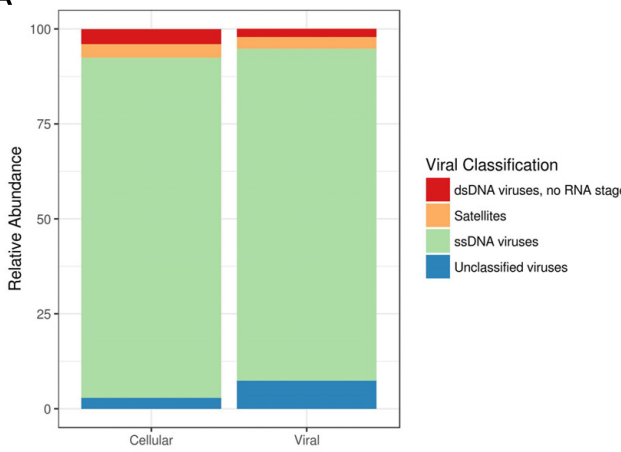

C

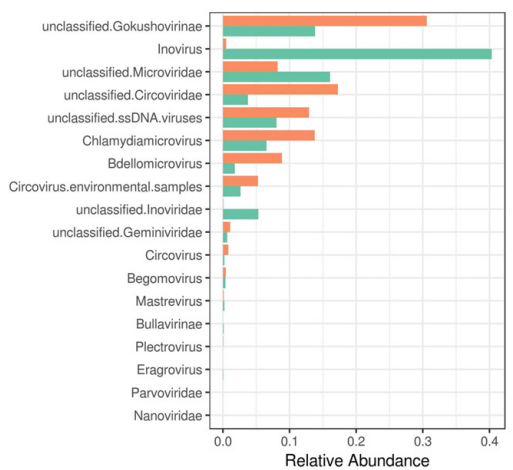

E

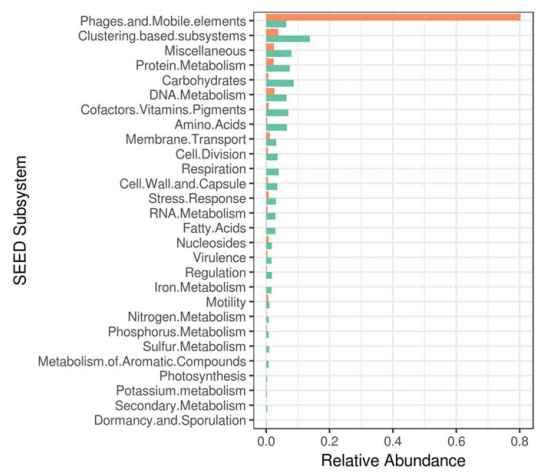

B

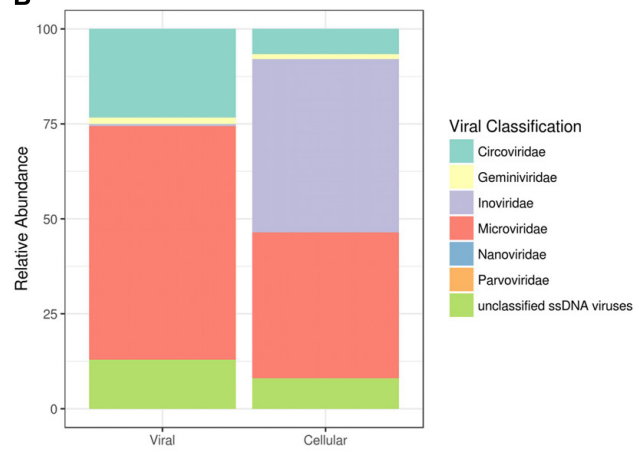

D

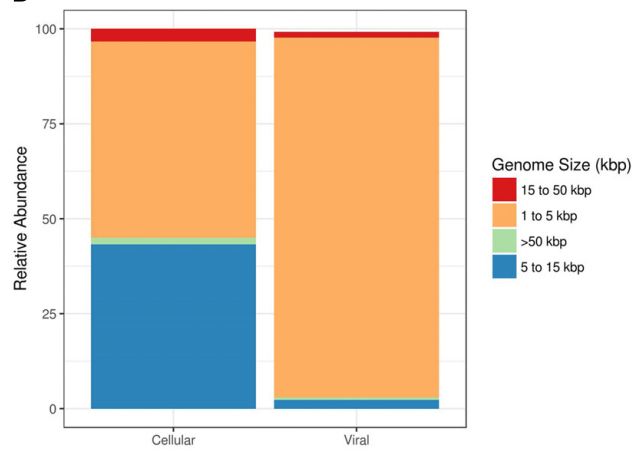

$\mathbf{F}$

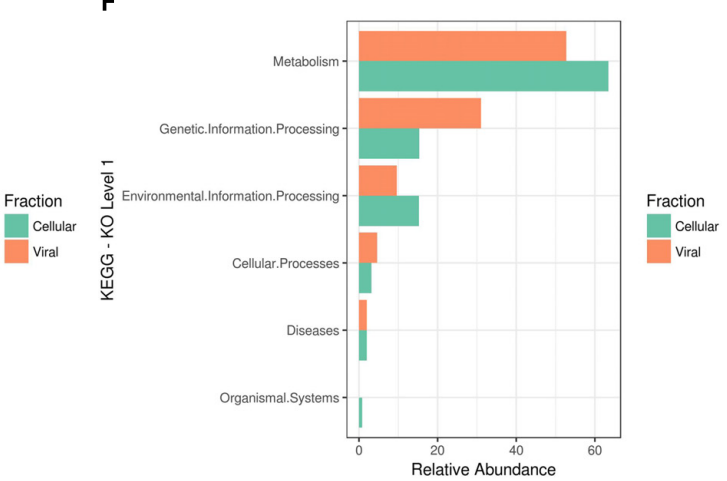

FIGURE 1 | Shark Bay viral and cellular fraction comparison. MG-RAST Functional annotations using KEGG (KO) and SEED where based on BLAT based comparison $\left(e\right.$-value $\left.\leq 10^{-5}\right)$ against respective database. (A) Viral taxonomic classification characterization by nucleic acid state in MetaVir2. (B) Viral taxonomic classification characterization by viral family in MetaVir2. (C) Viral taxonomic classification characterization by viral genus in MetaVir2 by cellular or viral fraction metagenome. (D) GAAS predictive viral genome size estimations in MetaVir2. (E) SEED subsystem functional annotations in MG-RAST. (F) KEGG (KO) level 1 functional annotations in MG-RAST. MetaVir2 viral (BLAST) based comparison (e-value $\leq 10^{-5}$ ) against NCBI viral refseq database and normalized to genome length using the built-in Genome-relative Abundance and Average Size (GAAS) normalization tool (Angly et al., 2006). 
identifier "Viral communities of Shark Bay modern stromatolites" (PRJNA471212).

\section{RESULTS AND DISCUSSION}

\section{General Properties of the Shark Bay Stromatolite Cellular and Viral Fraction Metagenomes}

DNA sequences for viral and cellular fractions from Shark Bay stromatolites were determined for viral homology and taxonomy using MetaVir2, and MG-RAST for functional annotation. Both the cellular and viral fraction have $>50,000$ sequences of $\sim 400 \mathrm{bp}$, with between 26 and $28 \mathrm{Mbp}$ total sequence length (Table 1). The viral fraction contained $50 \%$ annotated proteins with another $50 \%$ unknown proteins with no rRNA sequences, whereas the microbial fraction contained $64 \%$ annotated proteins with $33 \%$ unknown and 1.5\% rRNAs based on MG-RAST (Table 1). The lack of rRNA in the viral fraction, negative PCR results for bacterial 16S rDNA, and epifluorescence microscopy indicating no cells after filtration and $\mathrm{CsCl}$ gradient, suggests a relatively pure viral fraction. MetaVir2 predicted viral sequences based on BLAST to refseq (2017-01-11) found that regardless of the $e$-value $\left(10^{-3}, 10^{-5}, 10^{-7}\right.$ with GAAS normalization) that $>5 \%$ have a significant viral hit to known viruses within the database, whereas the cellular fraction had $>10 \%$ for significant viral hits (Table 1). An $e$-value of $10^{-5}$ with GAAS normalization was chosen for all further taxonomic and viral genome size estimation using MetaVir2, and an $e$-value of $10^{-5}$ for MG-RAST functional annotation for its conservative value while providing the most significant hits to known databases. Assembly was completed on the viral fraction only in an attempt to find circular ssDNA putative genomes and longer contigs (Table 1). Ray assembly of the Shark Bay viral fraction yielded few contigs ( 49 at $>500 \mathrm{bp}$, 500 at $>100 \mathrm{bp}$ ) suggesting sparse sampling of the available ssDNA viruses found at Shark Bay (Table 1).

\section{Shark Bay Stromatolite Virome and ssDNA Virus Diversity}

ssDNA viruses were the most abundant amongst the viral sequences due to the enrichment of phi29-based MDA of the Shark Bay stromatolite viral fraction (i.e., free viral particles). It is important to note that few sequences within the Shark Bay virome had representative annotated hits to known viral genomes, and downstream analyses described are based on known annotated viral genomes present within MetaVir2. More than $85 \%$ of reads relating to viruses in the viral and cellular fraction from Shark Bay were ssDNA viruses ( $e$-value $\leq 10^{-5}$ with GAAS normalization) (Figure 1A). Microviridae represented $>50 \%$ of annotated ssDNA virus sequences within the viral fraction and $>30 \%$ in the cellular fraction (Figure 1B). The cellular fraction had $\sim 40 \%$ Inoviridae sequences whereas the viral fraction had $<1 \%$ (Figure 1B). The Inoviridae sequences were $~ 35 \%$ inovirus in the cellular fraction with some unclassified members (Figure 1C). Microviridae in Shark Bay are likely directly infecting hosts, as Microviridae are rarely lysogenic with the exception of the
TABLE 2 | KEGG ontology (KO) EC numbers for the Shark Bay virome annotations reads.

\begin{tabular}{|c|c|c|}
\hline EC description & EC number & Abundance \\
\hline $\begin{array}{l}\text { DNA } \\
\text { (cytosine-5-)-methyltransferase }\end{array}$ & 2.1.1.37 & 36 \\
\hline $\begin{array}{l}\text { Ribonucleoside-diphosphate } \\
\text { reductase }\end{array}$ & 1.17.4.1 & 11 \\
\hline DNA helicase & 3.6.4.12 & 8 \\
\hline GDP-mannose 4,6-dehydratase & 4.2.1.47 & 5 \\
\hline Riboflavin kinase & 2.7.1.26 2.7.7.2 & 5 \\
\hline Methyltransferases & 2.1.1.- & 4 \\
\hline $\begin{array}{l}\text { Carbon-oxygen } \\
\text { lyases/Hydro-lyases }\end{array}$ & 4.2.1.- & 3 \\
\hline Spermidine dehydrogenase & 1.5.99.6 & 3 \\
\hline DNA-directed DNA polymerase & 2.7.7.7 & 2 \\
\hline Nicotinamidase & 3.5.1.19 3.5.1.- & 2 \\
\hline $\begin{array}{l}\text { Ribonucleoside-triphosphate } \\
\text { reductase }\end{array}$ & 1.17.4.2 & 2 \\
\hline Nucleotidyltransferases & 2.7.7.- & 2 \\
\hline Thymidylate synthase & 2.1.1.148 & 2 \\
\hline Sarcosine oxidase & 1.5.3.1 & 2 \\
\hline Leucyl aminopeptidase & 3.4 .11 .1 & 2 \\
\hline Xanthine dehydrogenase & 1.17.1.4 & 1 \\
\hline Aspartate carbamoyltransferase & 2.1.3.2 & 1 \\
\hline Deoxyuridine-triphosphatase & 3.6.1.23 & 1 \\
\hline Histidine permease & 3.6.3.21 & 1 \\
\hline Amidophosphoribosyltransferase & 2.4.2.14 & 1 \\
\hline Indolepyruvate decarboxylase & 4.1.1.74 & 1 \\
\hline $\begin{array}{l}\text { NAD+ synthase } \\
\text { (glutamine-hydrolysing) }\end{array}$ & 6.3.5.1 & 1 \\
\hline Allantoicase & 3.5.3.4 & 1 \\
\hline Peptidyl-dipeptidase A & 3.4.15.1 & 1 \\
\hline Dihydrofolate reductase & 1.5.1.3 2.1.1.45 & 1 \\
\hline GDP-L-fucose synthase & 1.1.1.271 & 1 \\
\hline DNA-directed RNA polymerase & 2.7.7.6 & 1 \\
\hline $\begin{array}{l}\text { UDP-N-acetylglucosamine-1- } \\
\text { carboxyvinyltransferase }\end{array}$ & 2.5.1.7 & 1 \\
\hline Tryptophan synthase & 4.2 .1 .20 & 1 \\
\hline $\begin{array}{l}\text { 3-oxoacyl-[acyl-carrier-protein] } \\
\text { reductase }\end{array}$ & 1.1 .1 .100 & 1 \\
\hline $\begin{array}{l}\text { Oxidoreductases with NAD+ or } \\
\text { NADP+ as acceptors }\end{array}$ & 1.1.1.- & 1 \\
\hline Protoporphyrinogen oxidase & 1.3.3.4 & 1 \\
\hline
\end{tabular}

MG-RAST cut-offs were at 1e-5 e-value, min\% identity of $60 \%$, and minimum alignment length of $50 \mathrm{bp}$.

proviruses that infect Bacteroidetes (Krupovic and Forterre, 2011). Microviridae as a group are more often found to be lytic than lysogenic, and thus the higher presence of Microviridae annotated sequences in the cellular fraction in the present study could potentially be active infection (Szekely and Breitbart, 2016). Chlamydiamicroviruses composed $12 \%$ of the Microviridae sequences amongst the Shark Bay virome (Figure 1C), and these were dominated by subfamily Gokushovirinae at 27\% (Figure 1C). The gokushoviruses have been shown to be widespread in many marine ecosystems (Hopkins et al., 2014). Amongst the Chlamydiamicroviruses sequences within the 

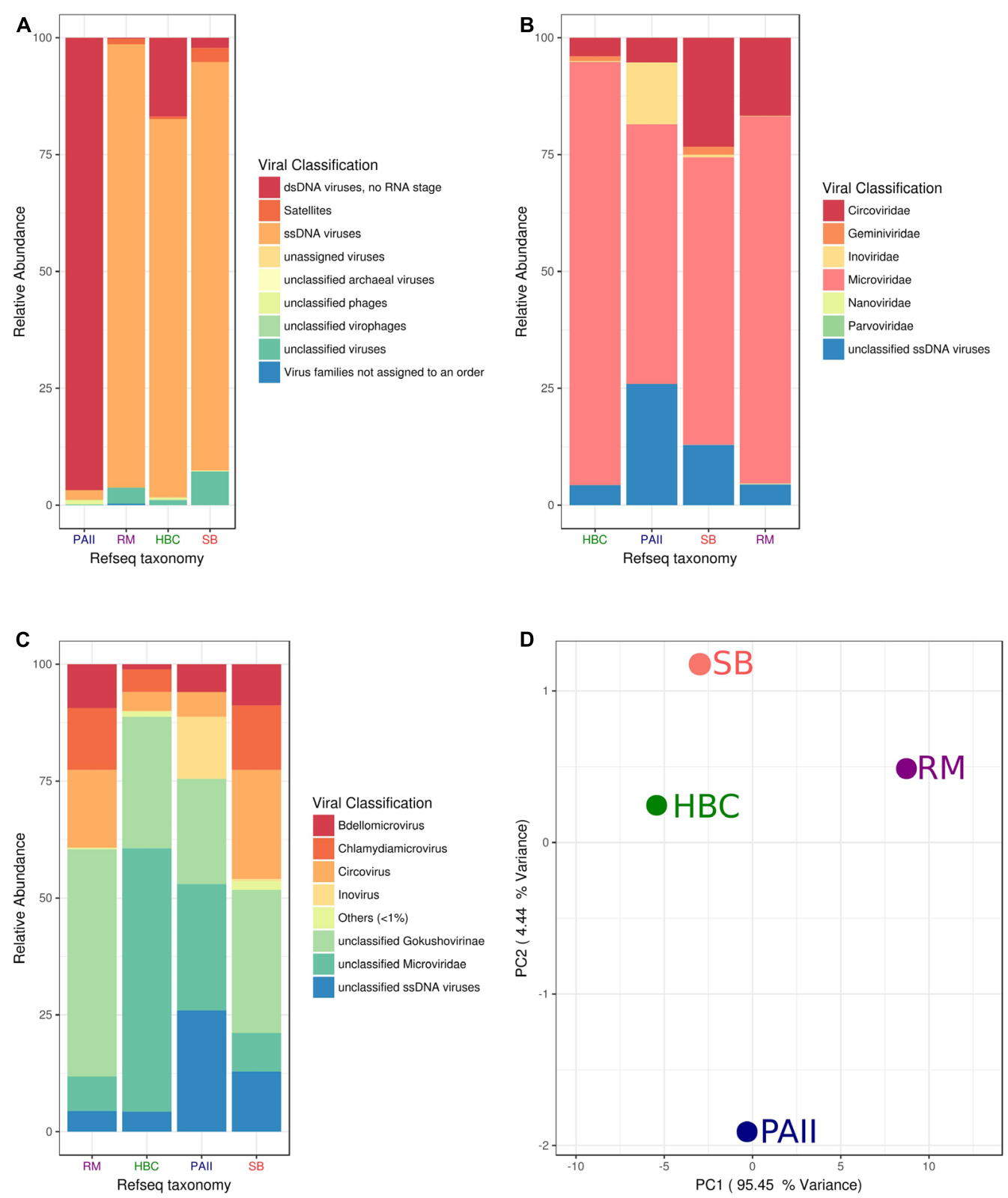

FIGURE 2 | Viral fraction comparison Shark Bay against Highbourne Cay, Rios Mesquites and Pozas Azules II microbialite sites. (A) Viral taxonomic classification characterization by nucleic acid state in MetaVir2. (B) Viral taxonomic classification characterization by viral family in MetaVir2. (C) Viral taxonomic classification characterization by viral genus in MetaVir2. (D) Principal coordinate analyses (PCA) comparing the viral diversity in disparate stromatolite locations. PCA were constructed from similarity matrices utilizing protein coding sequence recruitment using NCBI viral refseq database (refseq update 2017-1-11) and normalized to genome length using the built-in GAAS. Proportion variance (PC) was explained by each component printed next to the PC1/PC2 axes labels. MetaVir2 viral (BLAST) based comparison (e-value $\leq 10^{-5}$ ) against NCBI viral refseq database and normalized to genome length using the built-in Genome-relative Abundance and Average Size (GAAS) normalization tool (Angly et al., 2006). MG-RAST Functional annotations using KEGG (KO) and SEED where based on BLAT based comparison $\left(e\right.$-value $\leq 10^{-5}$ ) against respective database. SB, Shark Bay; HBC, Highbourne Cay; PAll, Pozas Azule II; RM, Rio Mesquites.

Shark Bay virome, some sequences were most similar to chlamydia phage 3 and 4-like sequences (Supplementary Table 1). Bdellomicrovirus sequences also comprised $\sim 8 \%$ of the Shark Bay Microviridae sequences, and this virus is known to infect the bacterium Bdellovibrio.

Genome-relative abundance and average size normalization allowed for general prediction of the relative viral genome size for both cellular and viral fraction using MetaVir2 with large differences between the two fractions. Greater than $90 \%$ of the predicted genome sizes within the viral fraction were $1-5 \mathrm{kbp}$ (Figure 1D). In contrast $\sim 50 \%$ was represented in the predictive genome size of 1-5 kbp (Figure 1D) in the cellular fraction. The other $\sim 40 \%$ were predicted to be viral genomes of $5-15 \mathrm{kbp}$ (Figure 1D). The likely reason for this selectively lower viral 
TABLE 3 | BLAST results against NCBI against long contigs and putative viral genomes in the Shark Bay viral fraction.

\begin{tabular}{|c|c|c|c|c|c|c|c|}
\hline & Gene & Max score & Total score & Query cover $\%$ & $E$-value & Ident \% & Accession \\
\hline \multicolumn{8}{|l|}{ contig-7000012_1784 } \\
\hline Uncultured virus & $\begin{array}{l}\text { Viral replication-associated } \\
\text { protein (Rep) }\end{array}$ & 172 & 172 & 56.00 & $1.00 E-44$ & 34.00 & AUM61732.1 \\
\hline Uncultured virus & $\begin{array}{l}\text { Viral replication-associated } \\
\text { protein (Rep) }\end{array}$ & 171 & 171 & 57.00 & $4.00 E-43$ & 33.00 & AUM62051.1 \\
\hline $\begin{array}{l}\text { Sewage-associated circular } \\
\text { DNA virus-30 }\end{array}$ & $\begin{array}{l}\text { Viral replication-associated } \\
\text { protein (Rep) }\end{array}$ & 166 & 166 & 52.00 & $2.00 E-41$ & 32.00 & YP_009117070.1 \\
\hline \multicolumn{8}{|l|}{ contig-1000003_2028 } \\
\hline $\begin{array}{l}\text { Sewage-associated circular } \\
\text { DNA virus-18 }\end{array}$ & $\begin{array}{l}\text { Viral replication-associated } \\
\text { protein (Rep) }\end{array}$ & 170 & 170 & 50.00 & $2.00 E-43$ & 31.00 & YP_009116898.1 \\
\hline Uncultured virus & $\begin{array}{l}\text { Viral replication-associated } \\
\text { protein (Rep) }\end{array}$ & 169 & 169 & 47.00 & $1.00 E-42$ & 33.00 & AUM61781.1 \\
\hline Uncultured virus & $\begin{array}{l}\text { Viral replication-associated } \\
\text { protein (Rep) }\end{array}$ & 164 & 164 & 49.00 & $2.00 E-41$ & 34.00 & AUM61982.1 \\
\hline \multicolumn{8}{|l|}{ Contig-1000009_1678 } \\
\hline Ralstonia picketti & Hypothetical protein & 636 & 636 & 55.00 & 0 & 99.00 & WP_024972784.1 \\
\hline $\begin{array}{l}\text { Cellulophaga phage } \\
\text { phi47:1 }\end{array}$ & $\begin{array}{l}\text { Hypothetical protein } \\
\text { CDPG_00080 }\end{array}$ & 629 & 629 & 54.00 & 0 & 99.00 & AGF91683.1 \\
\hline $\begin{array}{l}\text { Cellulophaga phage } \\
\text { phi47:1 }\end{array}$ & $\begin{array}{l}\text { Hypothetical protein } \\
\text { CDPG_00081 }\end{array}$ & 276 & 276 & 27.00 & $3.00 E-87$ & 100.00 & AGF91684.1 \\
\hline \multicolumn{8}{|l|}{ contig-1000007_1202 } \\
\hline $\begin{array}{l}\text { Pseudanabaena sp. } \\
\text { 'Roaring Creek }\end{array}$ & Hypothetical protein & 45.8 & 45.8 & 13.00 & 0.019 & 45.00 & WP_055077263.1 \\
\hline $\begin{array}{l}\text { Synechococcus sp. PCC } \\
7502\end{array}$ & Hypothetical protein & 42 & 42 & 11.00 & 0.093 & 50.00 & WP_015169903.1 \\
\hline $\begin{array}{l}\text { Oscillatoriales } \\
\text { cyanobacterium USR001 }\end{array}$ & $\begin{array}{l}\text { Hypothetical protein } \\
\text { BCD67_24715 }\end{array}$ & 39.3 & 39.3 & 15.00 & 2.1 & 31.00 & OCQ97517.1 \\
\hline \multicolumn{8}{|l|}{ contig-4_4099 } \\
\hline Uncultured prokaryote & Hypothetical protein & 48.1 & 48.1 & 11.00 & 0.037 & 27.00 & CRY97485.1 \\
\hline Uncultured prokaryote & Hypothetical protein & 41.6 & 41.6 & 3.00 & 5.3 & 46.00 & CRY96835.1 \\
\hline $\begin{array}{l}\text { Actinoplanes subtropicus } \\
\text { contig-2000010_3827 }\end{array}$ & Recombinase family protein & 42.7 & 42.7 & 4.00 & 6.7 & 39.00 & WP_084599775.1 \\
\hline Uncultured prokaryote & Hypothetical protein & 75.9 & 75.9 & 11.00 & $6.00 \mathrm{E}-11$ & 34.00 & CRY96346.1 \\
\hline Azospirillum sp. 51_20 & Hypothetical protein & 72.4 & 72.4 & 4.00 & 2.00E-09 & 57.00 & OLA80278.1 \\
\hline \multicolumn{8}{|l|}{ contig-1000002_2208 } \\
\hline Tateyamaria omphalii & $\begin{array}{l}\text { DNA ligase-associated DEXH } \\
\text { box helicase }\end{array}$ & 42.4 & 42.4 & 18.00 & 4.5 & 29.00 & WP_076628122.1 \\
\hline Streptomyces & $\begin{array}{l}\text { MULTISPECIES: } \\
\text { serine/threonine protein kinase }\end{array}$ & 42 & 42 & 19.00 & 7.1 & 28.00 & WP_103536509.1 \\
\hline \multicolumn{8}{|l|}{ Contig-9_1603 } \\
\hline \multicolumn{8}{|l|}{ No hits } \\
\hline \multicolumn{8}{|l|}{ Contig-8_1554 } \\
\hline \multicolumn{8}{|l|}{ No hits } \\
\hline \multicolumn{8}{|l|}{ Contig-7_1473 } \\
\hline No hits & & & & & & & \\
\hline
\end{tabular}

genome is due to the phi29-mediated amplification, and future work is needed to amplify the majority of viral nucleic acids without dsDNA or ssDNA biases.

The top functional genes present and SEED subsystems for Shark Bay viral fraction included $>80 \%$ in related to phages, prophages, transposable elements, and/or plasmids (Figure 1E). KEGG KO level 1 annotation for both viral and cellular fraction suggested metabolism $>40 \%$ represented most functional calls by
KEGG (Figure 1F). KEGG EC included phage viral structural genes (e.g., capsids, tails, Table 2) and DNA metabolism related genes (e.g., DNA 5-cytosine methylase, ribonucleosidediphosphate reductase, and DNA helicase, Table 2). These functional genes potentially facilitate key processes in the Shark Bay stromatolite host communities, including viral attachment, protection of viral genetic material, and viral replication (Hofer, 2016). 
Surprisingly, no haloarchaeal viruses were identified here, although haloarchaea are prominent in the Shark Bay microbialite systems (Burns et al., 2004; Allen et al., 2009; Wong et al., 2017), and have been hypothesized to 'fill the niche' as potentially major players in nutrient cycles. Despite the lack of haloarchaeal viruses/phage amongst our data, there were unclassified sequences from assembled contigs $\sim 25 \%$ or $\sim 1.08 \%$ unassembled reads (Table 1 ) with no hits to public databases, and haloarchaeal viral genes could putatively be amongst these. In addition, two of the putative viral contigs which contain only replication protein genes could be associated with haloarchaea.

\section{Comparison Between Shark Bay Virome and Microbial Fraction With Other Microbialite Ecosystems}

Shark Bay viral and cellular fraction metagenomes were compared to previously reported microbialite ecosystems (Highbourne Cay, Pozas Azules II, and Rios Mesquites). Microviridae sequence dominance within the Highbourne Cay viromes has been previously noted (Desnues et al., 2008), and the Shark Bay viromes were very similar in viral taxonomic composition (Figure 2A). Highbourne Cay, Rios Mesquites and Shark Bay viromes had $>80 \%$ of sequences as ssDNA viruses

A

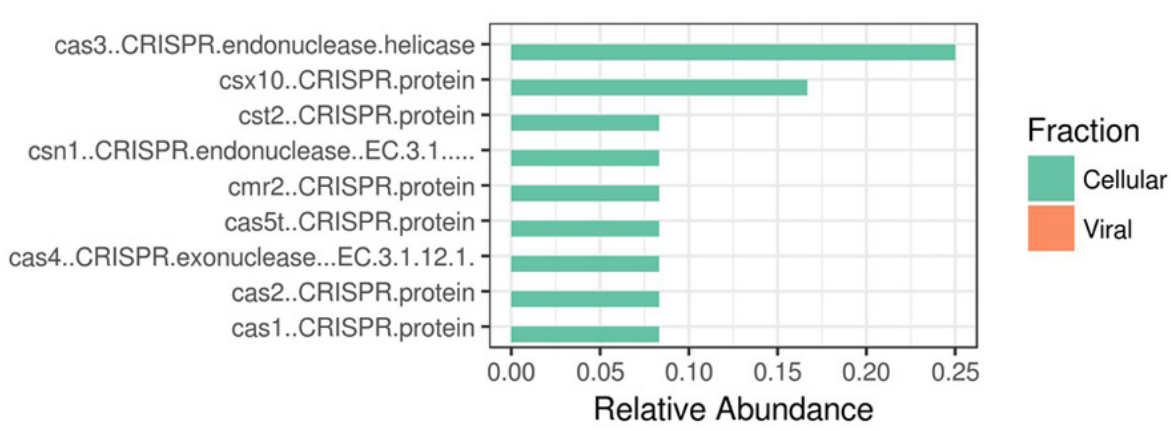

B
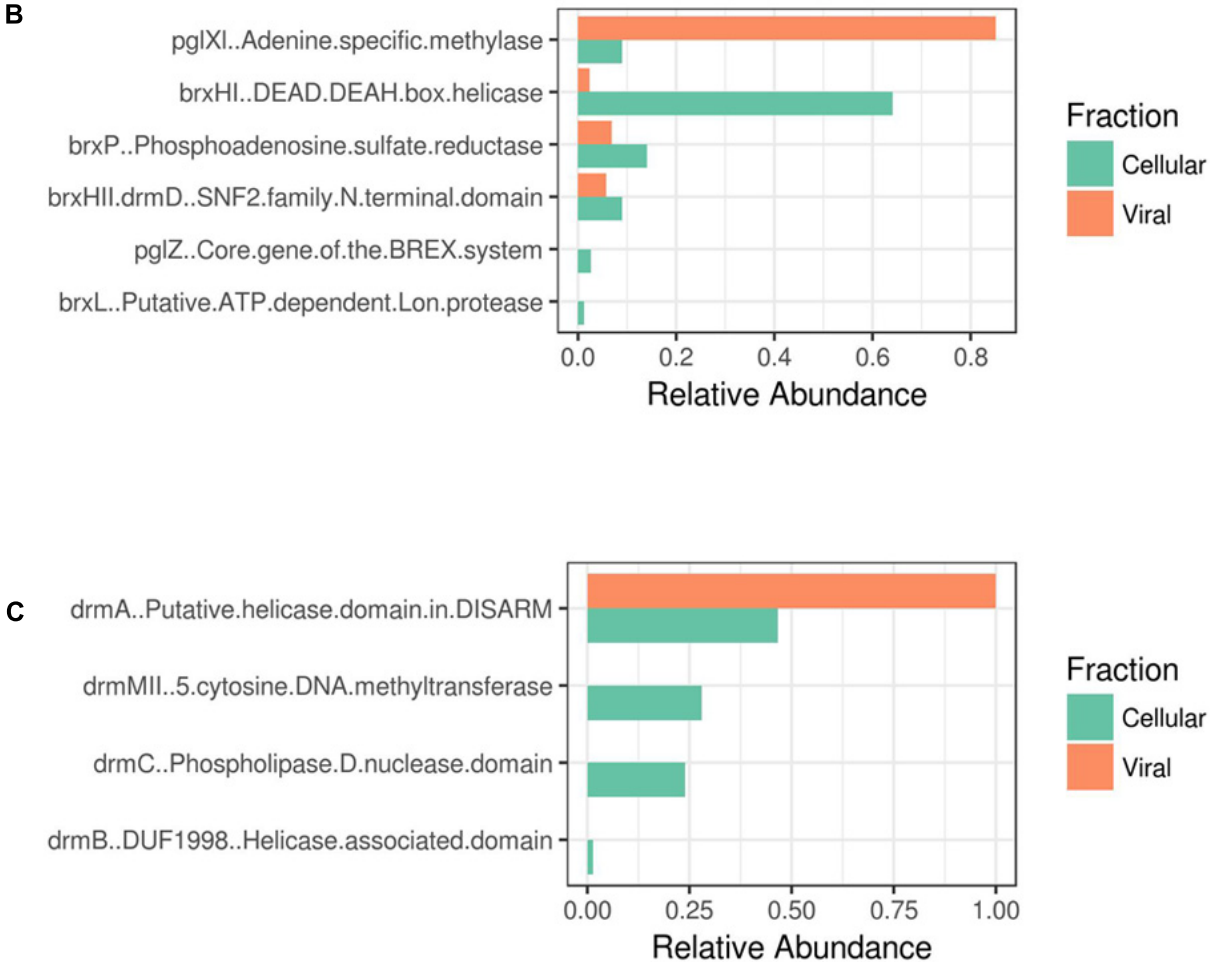

FIGURE 3 | Antiviral resistance genes amongst Shark Bay viral and cellular fraction. (A) CRISPR-Cas associated genes (B) BREX associated genes (C) DISARM associated genes. The relative abundance is the number of hits from GhostKoala and the Pfam database using InterProScan 5. 
(Figure 2A), which may be attributed to phi29-mediated bias. Of those ssDNA sequences, Highbourne Cay, Rios Mesquites and Shark Bay $>50 \%$ were of Microviridae-like sequences, with Shark Bay virome having $>20 \%$ of circoviridae origin (Figure 2B). Pozas Azules II had $>90 \%$ as dsDNA virus sequences (Desnues et al., 2008). Data here was normalized to $100 \%$ for ssDNA virus sequences for Pozas Azules II to compare ssDNA viruses across all four sites, with Pozas Azules II possessing $>50 \%$ Microviridae-like sequences after normalization comprising the bulk of the ssDNA sequences in that ecosystem. There were some compositional differences between Shark Bay and Highbourne Cay viromes, as Shark Bay had $>25 \%$ of the sequences with similarity to Chlamydia phage 3 and 4 (represented as Chlamydiamicrovirus), whereas Highbourne Cay had $>20 \%$ of the sequences with similarity to unclassified Microviridae (Figure 2C). Shark Bay ssDNA virus sequences were highly similar and clustered with Highbourne Cay viromes (Figure 2D).
The presence of the high levels of ssDNA sequences explained the majority of principal coordinate clustering observed (Figure 2D).

\section{Long Viral Contigs and Putative Viral Genomes in Shark Bay Stromatolites}

Two of the contigs obtained from the Shark Bay viral fraction (the largest contigs) have no BLAST hits to any reference sequence in NCBI databases. SB contig-2000010_3827 (3827 bp) and contig4_4099 (4099 bp) have low E-values $\left(\sim 1 \times 10^{3}\right)$ to hypothetical proteins or recombinases (Table 3 ). Two of the contigs (7000012_1784 and 1000003_2028) are putative viral genomes as they are circular and have homologs to replication protein (e.g., Rep), and related to Sewage-associated circular DNA virus30 and Sewage-associated circular DNA virus-18 respectively (Table 3). Both of these viruses, Sewage-associated circular DNA virus-30 and Sewage-associated circular DNA virus-18,

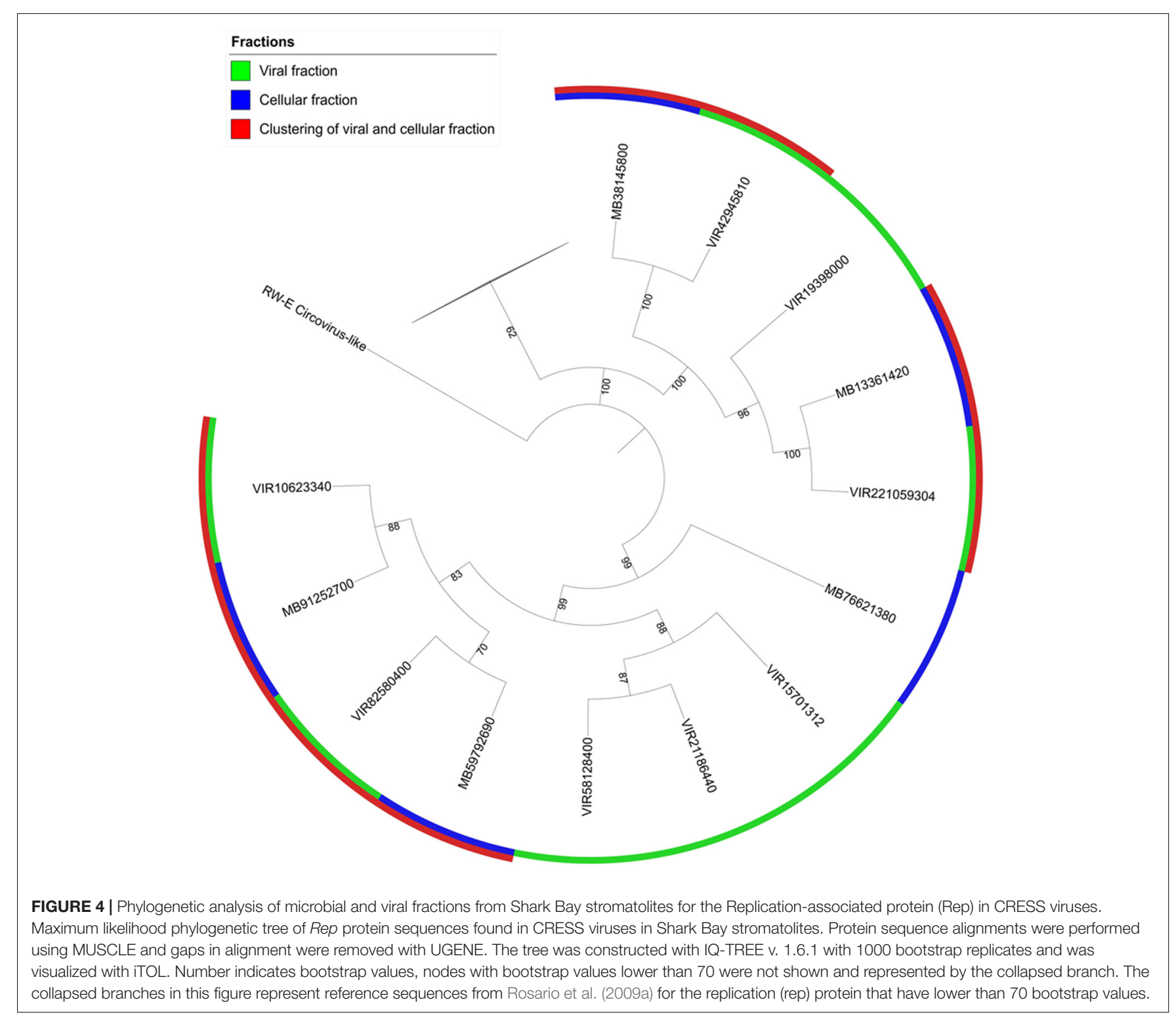


are novel circular replication-associated protein encoding singlestranded (CRESS) DNA viral genomes (Kraberger et al., 2015). These viruses are classified now as novel Genomoviridae within CRESS family (Krupovic et al., 2016), whereas the hosts of these viruses are unknown most members infect eukaryotes associated with infecting plants and animals not bacteria. These viruses could be introduced to microbialite systems by seabirds endemic to an area (Desnues et al., 2008), a scenario that could also potentially be occurring in Shark Bay.

\section{Environmental Relevance of ssDNA Viruses in Shark Bay}

Eukaryotic grazers represent a potential destabilizing factor by grazing nutrient rich stromatolites, including Shark Bay

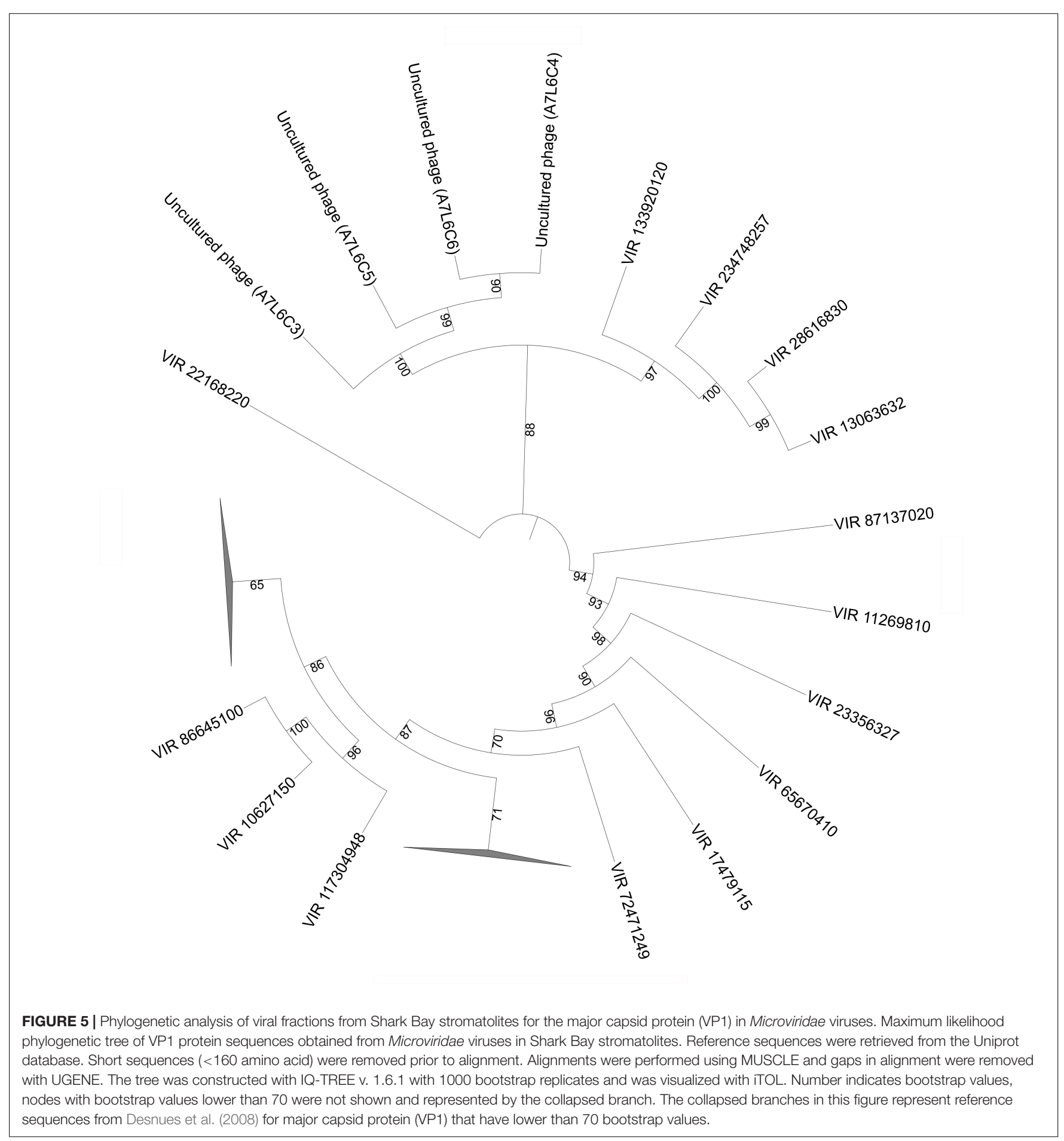




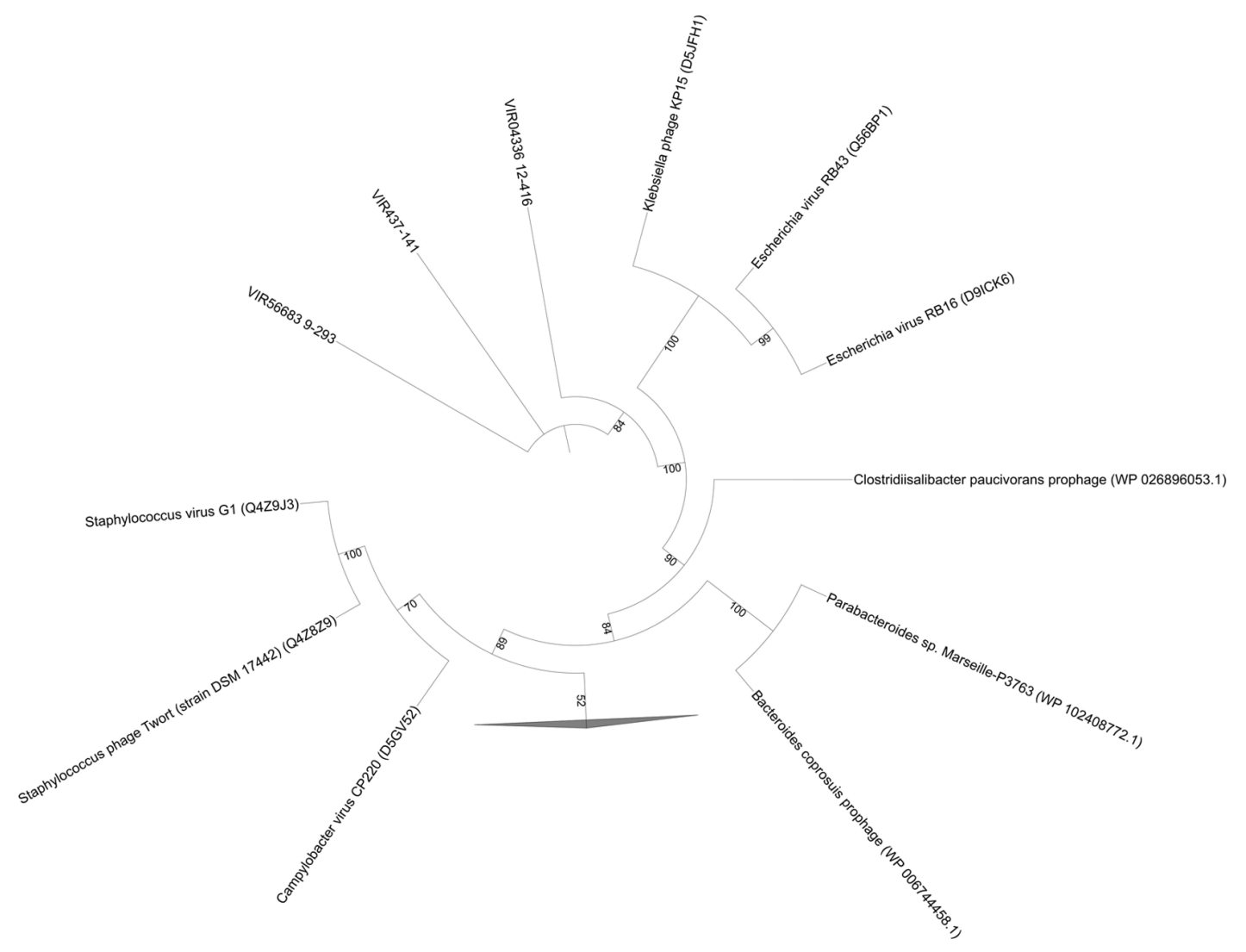

FIGURE 6 | Phylogenetic analysis of viral fractions from Shark Bay stromatolites for phoH (of the pho regulon) in dsDNA viruses. Maximum-likelihood tree of phoH protein sequences obtained from dsDNA viruses. Reference sequences were retrieved from Uniprot database. Alignments were performed using MUSCLE and gaps in alignment were removed with UGENE. The tree was constructed with IQ-TREE v. 1.6.1 with 1000 bootstrap replicates and was visualized with iTOL. Number indicates bootstrap values, nodes with bootstrap values lower than 70 were not shown and represented by the collapsed branch. The collapsed branches in this figure represent reference sequences from Goldsmith et al. (2011) for the phosphate starvation inducible protein (phoH) that have lower than 70 bootstrap values.

TABLE 4 | BLAST results against NCBI for phoH sequences in the Shark Bay viral fraction.

\begin{tabular}{|c|c|c|c|c|c|c|c|c|}
\hline $\begin{array}{l}\text { phoH } \\
\text { sequences }\end{array}$ & Gene name & Species & $\begin{array}{l}\text { Max } \\
\text { score }\end{array}$ & $\begin{array}{l}\text { Total } \\
\text { score }\end{array}$ & $\begin{array}{c}\text { Query } \\
\text { cover \% }\end{array}$ & $E$-value & Ident \% & Accession \\
\hline \multirow[t]{3}{*}{$\begin{array}{l}\text { Sequence } \\
\text { VIR56683 9-293 }\end{array}$} & PhoH family protein & $\begin{array}{l}\text { Parabacteroides sp. } \\
\text { Marseille-P3763 }\end{array}$ & 110 & 110 & 96.00 & $1.00 E-26$ & 56.00 & WP_102408772.1 \\
\hline & PhoH family protein & Bacteroides coprosuis & 110 & 110 & 96.00 & 2.00E-26 & 58.00 & WP_006744458.1 \\
\hline & PhoH family protein & Defluviitoga tunisiensis & 110 & 110 & 97.00 & 2.00E-26 & 50.00 & WP_045087935.1 \\
\hline \multirow[t]{3}{*}{$\begin{array}{l}\text { Sequence } \\
\text { VIR437-141 }\end{array}$} & $\begin{array}{l}\text { hypothetical protein } \\
\text { D478_16524 }\end{array}$ & $\begin{array}{l}\text { Brevibacillus agri } \\
\text { BAB-2500 }\end{array}$ & 112 & 112 & 98.00 & 3.00E-30 & 56.00 & ELK40902.1 \\
\hline & PhoH family protein & $\begin{array}{l}\text { Clostridiisalibacter } \\
\text { paucivorans }\end{array}$ & 119 & 119 & 98.00 & $1.00 E-29$ & 60.00 & WP_026896053.1 \\
\hline & ATPase & $\begin{array}{l}\text { Bacillus boroniphilus } \\
\text { JCM } 21738\end{array}$ & 107 & 107 & 98.00 & $3.00 E-28$ & 54.00 & GAE45877.1 \\
\hline \multirow[t]{3}{*}{$\begin{array}{l}\text { Sequence } \\
\text { VIR04336 12-416 }\end{array}$} & PhoH family protein & $\begin{array}{l}\text { Moorella } \\
\text { thermoacetica }\end{array}$ & 148 & 148 & 98.00 & $3.00 E-40$ & 52.00 & WP_075517747.1 \\
\hline & PhoH family protein & $\begin{array}{l}\text { Clostridiisalibacter } \\
\text { paucivorans }\end{array}$ & 147 & 147 & 100.00 & 1.00E-39 & 52.00 & WP_026896053.1 \\
\hline & PhoH family protein & Alteribacillus iranensis & 145 & 145 & 99.00 & 3.00E-39 & 50.00 & WP_091657652.1 \\
\hline
\end{tabular}

stromatolites (Farmer, 1992; Edgecomb et al., 2014). Marine geminiviruses and circoviruses infect a wide range of eukaryotic organisms, including protists, marine arthropods, and other grazers (Rosario et al., 2009a; Saccardo et al., 2011). We hypothesize that the marine viruses identified in the present study may infect eukaryotic grazers, with the viruses acting act 
as a top-down control. Viral mediated lysis of eukaryotic grazers may help stabilize the stromatolite ecosystems in Shark Bay, that could otherwise be disrupted by excessive grazing. While the aforementioned viruses are obligate eukaryotic-associated, the Shark Bay virome contains viruses similar to those also capable of infecting bacteria, such as the Bdellomicroviruses (Figure 2). Future studies are needed in eukaryotic circular Rep-encoding ssDNA (CRESS) viruses within Shark Bay stromatolites and other environments, to measure the rates of viral mediated lysis of eukaryotes amongst phytoplankton and zooplankton, as such top-down control could have global impacts of nutrient cycling in the ocean. Single cell techniques may elucidate such viral-host (e.g., protist-viral) interactions (Gavelis et al., 2015). Recent studies employing iTag deep amplicon sequencing of bacterial communities in Shark Bay microbialites indeed identified Bdellovibrio as one of the prominent community members (Wong et al., 2015). Thus, the potential for infection by this group of viruses with known microbialite hosts in Shark Bay is present, and future work will help clarify the extent of this process in these ecosystems.

\section{Microbial Viral Defense Mechanisms in Shark Bay Stromatolites}

Furthermore, metagenomic analysis of Shark Bay stromatolites has revealed putative viral defense mechanisms present. Evidence of CRISPR-Cas, BREX (bacteriophage exclusion), and DISARM (defense island system associated with restriction-modification) (Goldfarb et al., 2015; Ofir et al., 2018) in both the viral and cellular fraction metagenomes from Shark Bay were found in the present study (Figure 3). The genetic basis of one such mechanism, CRISPR (clustered, regularly interspaced, short palindromic repeat systems), was also identified in the Shark Bay microbial metagenomes (Ruvindy et al., 2016). When compared to the viral fraction, an enrichment of CRISPR-Cas genes was observed in the cellular fraction with none in the viral fraction (Figure 3A). BREX genes are also more abundant in the cellular fraction than the viral fraction (Figure 3B), with the viral fraction having an abundance of Adenine-specific methylase that may putatively be used against host methylation of viral DNA (Figure 3B). DISARM genes were also enriched in the cellular vs. viral fraction (Figure 3C), including the primary helicases. This is the first evidence of DISARM and BREX in metagenomes enriched in cellular fractions associated with stromatolites. CRISPR systems have been identified as an adaptive microbial immune system that provides acquired immunity against viruses (Horvath and Barrangou, 2010), and thus there may be an interplay between the viral populations identified in the present study and the defense mechanisms characterized in host Shark Bay populations.

A recent study of freshwater microbialites in Pavilion Lake, BC suggested that T4-like phage (e.g., Myoviridae) and large algal viruses (e.g., Phycodnaviridae) dominated the viral sequences in the water compared to microbialites, whereas the microbialites possessed genes related to viral defense (e.g., CRISPR, phage shock and phage excision) (White et al., 2016a). Future metagenomic sequencing efforts in Shark Bay should target in detail the two novel viral defense systems of BREX and DISARM, to help complete our understanding of the viral load in the modern microbialites of Shark Bay.

\section{Phylogenetics of Shark Bay Stromatolite Viral Fraction}

Circovirus-like viruses were also detected in Shark Bay viromes (Figure 2C), which are thought to associate with and potentially infect eukaryotic grazers, such as insects, snails, and other marine arthropods (Rosario et al., 2009a). Closely related Rep-encoding sequences were found in both the cell and viral fractions, indicative of the potential active infection amongst bacterial cells (Figure 4). Phylogenetic tree constructed indicates there are four pairs of contigs from microbial fraction and viral fraction that clustered together (Figure 4). These viruses in the viral fraction were found amongst the microbialite itself suggesting potential active infection by ssDNA could be occurring in Shark Bay stromatolites. Eukaryotic grazers can feed on cyanobacterial mats that are the basal unit of stromatolite formation, stability and construction, and thus the presence of viruses that infect and inhibit these grazers could be a top-down control and maintenance of the stromatolite ecosystem in Shark Bay.

Viral capsid protein gene (VP1) for microphages (i.e., Microviridae) was first described in stromatolites from Highbourne Cay, Rios Mesquites, and Pozas Azules II (Desnues et al., 2008). In the present study, the VP1 sequences obtained in the Shark Bay viral fraction have expanded the quantity of known VP1 sequences (Figure 5), and BLAST results also indicate that the branches are derived from uncultured phages. The potential hosts for these VP1-like sequences are likely bacterial hosts over eukaryotes due to their homology to uncultured phages.

As mentioned above, $\mathrm{PhoH}$ is a viral AMG with unknown function. Phosphorus limitation has been reported in previous studies in Shark Bay (Smith and Atkinson, 1984; Atkinson, 1987; Wong et al., 2015), as well as in freshwater microbialites (White et al., 2015, 2016a,b). The pho regulon as well as a high abundance of alkaline phosphatases were found amongst the columnar stromatolite (microbial fraction) analyzed here (Figure 6), as well as in a previous study (Ruvindy et al., 2016). This regulon has also been identified in soda lake microbialites of Mexico (Valdespino-Castillo et al., 2014). After further BLAST analysis of the phoH sequences in the present study, it was confirmed by manual examination of the reference genomes that they are viral phoH sequences from prophage in these bacterial genomes (Table 4 and Figure 6). Inducible prophages are often found in marine systems that infect large groups of bacteria including marine aerobic anoxygenic phototrophic bacteria (AAPB) (Zheng et al., 2014). These prophage appeared to be integrated into the genomes of Clostridiisalibacter paucivorans and Bacteroides coprosuis DSM18011 (Table 4 and Figure 6). Other reference genomes in public databases are in draft form and annotations were unclear and unreliable, as the phoH accessions resided in regions of unknown or hypothetical proteins. While phoH has been found to be a core gene in T4-like phages, its function within ecosystems remains to be elucidated (Roux et al., 2015). However, we acknowledge that 
further investigation is warranted, and a more complete virome is needed for Shark Bay microbialites in order to ascertain whether phoH genes and complete pho regulons regulate phosphate uptake under low-phosphate conditions within Shark Bay.

\section{Potential Role of Viruses in Shark Bay}

Viruses are also well known as major players in marine nutrient cycling (Suttle, 2007), and they may also play such a role in Shark Bay systems. All viruses including ssDNA, dsDNA, and RNA viruses, are agents of cellular lysis due to infection and death. We hypothesize that the ssDNA viruses found in Shark Bay may be putative drivers of nutrient cycling mediated through eukaryotic and bacterial cell lysis, which releases dissolved nutrients (e.g., C, $\mathrm{P}, \mathrm{N}, \mathrm{S}$ ) to be utilized by other microbial community members as has been shown elsewhere (Bratbak et al., 1992; Gobler et al., 1997; Scanlan and Wilson, 1999; Jover et al., 2014). Viruses in Shark Bay are also likely to replenish dissolved organic carbon (DOC) upon cell lysis, thus also playing a role in the carbon cycle (Bratbak et al., 1992). However, further work is needed to delineate the exact role of viruses in biogeochemical cycling in these communities.

\section{CONCLUSION}

Data from the present study document for the first-time viral diversity amongst Shark Bay stromatolites. Although complete viral diversity remains to be captured due to potential phi29 polymerase MDA bias toward ssDNA viruses, the virome (i.e., viral fraction) revealed significant ssDNA viral diversity. Future work is needed on the viruses in microbialites and stromatolites of Shark Bay, potentially employing a long-read technology such as PacBio, Oxford Nanopore or Illumina Moleculo (White et al., 2016a), which could result in longer contigs, improved assemblies, and novel viral genomes. Microbialites and stromatolites provide modern models to ancient early complex

\section{REFERENCES}

Allen, M. A., Goh, F., Burns, B. P., and Neilan, B. A. (2009). Bacterial, archaeal and eukaryotic diversity of smooth and pustular microbial mat communities in the hypersaline lagoon of Shark Bay. Geobiology 7, 82-96. doi: 10.1111/j.1472-4669. 2008.00187.x

Angly, F. E., Felts, B., Breitbart, M., Salamon, P., Edwards, R. A., Carlson, C. et al. (2006). The marine viromes of four oceanic regions. PLoS Biol. 4:e368. doi: 10.1371/journal.pbio.0040368

Atkinson, M. (1987). Low phosphorus sediments in a hypersaline marine bay. Estuar. Coast. Shelf Sci. 24, 335-347. doi: 10.1016/0272-7714(87)90054-0

Boisvert, S., Laviolette, F., and Corbeil, J. (2010). Ray: simultaneous assembly of reads from a mix of high-throughput sequencing technologies. J. Comput. Biol. 17, 1519-1533. doi: 10.1089/cmb.2009.0238

Boisvert, S., Raymond, F., Godzaridis, E., Laviolette, F., and Corbeil, J. (2012). Ray Meta: scalable de novo metagenome assembly and profiling. Genome. Biol. 13:R122. doi: 10.1186/gb-2012-13-12-r122

Bratbak, G., Heldal, M., Thingstad, T. F., Riemann, B., and Haslund, O. H. (1992). Incorporation of viruses into the budget of microbial C-transfer: a first approach. Mar. Ecol. Prog. Ser. 83, 273-280. doi: 10.3354/meps 083273

Breitbart, M., and Rohwer, F. (2005). Here a virus, there a virus, everywhere the same virus? Trends. Microbiol. 6, 278-284. doi: 10.1016/j.tim.2005.04.003 ecosystems, and the data presented here is of significant value to our understanding of some of the first complex microbial ecosystems on Early Earth. Future work employing deeper sequencing and targeting other viruses will help further our understanding of viral diversity in these ecosystems in addition to the ssDNA viruses described here, and determine their exact contribution to functional complexity in Shark Bay.

\section{AUTHOR CONTRIBUTIONS}

RAW conducted the data analysis, assemblies, and wrote the manuscript sections. HW and RR conducted the data analysis, phylogenetic analysis, and contributed to manuscript sections. $\mathrm{BN}$ and $\mathrm{BB}$ coordinated and designed the research, and wrote manuscript sections. All the authors read and approved the manuscript.

\section{FUNDING}

This work was funded by the Australian Research Council.

\section{ACKNOWLEDGMENTS}

The authors would like to acknowledge the support of Forest Rohwer and Mya Breitbart in helping establish this project and facilitating sequencing.

\section{SUPPLEMENTARY MATERIAL}

The Supplementary Material for this article can be found online at: https://www.frontiersin.org/articles/10.3389/fmicb. 2018.01223/full\#supplementary-material

Burns, B. P., Goh, F., Allen, M., and Neilan, B. A. (2004). Microbial diversity of extant stromatolites in the hypersaline marine environment of Shark Bay, Australia. Environ. Microbiol. 6, 1096-1101. doi: 10.1111/j.1462-2920.2004. 00651.x

Desnues, C., Rodriguez-Brito, B., Rayhawk, S., Kelley, S., Tran, T., Haynes, M., et al. (2008). Biodiversity and biogeography of phages in modern stromatolites and thrombolites. Nature 452, 340-343. doi: 10.1038/nature06735

Dupraz, C., Reid, R. P., Braissant, O., Decho, A. W., Norman, R. S., and Visscher, P. T. (2009). Processes of carbonate precipitation in modern microbial mats. Earth Sci. Rev. 96, 141-162. doi: 10.1016/j.earscirev.2008.10.005

Dupraz, C., and Visscher, P. T. (2005). Microbial lithification in marine stromatolites and hypersaline mats. Trends Microbiol. 13, 429-438. doi: 10.1016/j.tim.2005.07.008

Edgar, R. C. (2004). MUSCLE: multiple sequence alignment with high accuracy and high throughput. Nucleic Acids Res. 32, 1792-1797. doi: 10.1093/nar/ gkh340

Edgecomb, V. P., Bernhard, J. M., Summons, R. E., Orsi, W., Beaudoin, D., and Visscher, P. T. (2014). Active eukaryotes in microbialites from Highbourne Cay, Bahamas, and Hamelin Pool (Shark Bay), Australia. ISME J. 8, 418-429. doi: 10.1038/ismej.2013.130

Farmer, J. D. (1992). "Grazing and bioturbation in modern microbial mats," in The Proterozoic Biosphere - A multidisciplinary Study, eds J. W. Schopf and C. Klein, (New York, NY: Cambridge University Press), 295-297. 
Gavelis, G. S., White, R. A. III, Suttle, C. A., Keeling, P. J., and Leander, B. S. (2015). Single-cell transcriptomics using spliced leader PCR: evidence for multiple losses of photosynthesis in polykrikoid dinoflagellates. BMC Genomics 16:528. doi: 10.1186/s12864-015-1636-8

Gobler, C. J., Hutchins, D. A., Fisher, N. S., Cosper, E. M., and Saňudo-Wilhelmy, S. (1997). Release and bioavailability of C, N, P, Se, and Fe following viral lysis of a marine Chrysophyte. Limnol. Oceanogr. 42, 1492-1504. doi: 10.4319/lo.1997. 42.7.1492

Goh, F., Allen, M. A., Leuko, S., Kawaguchi, T., Decho, A. W., Burns, B. P. et al. (2009). Determining the specific microbial populations and their spatial distribution within the stromatolite ecosystem of Shark Bay. ISME J. 4, 383-396. doi: 10.1038/ismej.2008.114

Goldfarb, T., Sberro, H., Weinstock, E., Cohen, O., Doron, S., Charpak-Amikam, Y., et al. (2015). BREX is a novel phage resistance system widespread in microbial genomes. EMBO J. 34, 169-183. doi: 10.15252/embj.20148 9455

Goldsmith, D. B., Crosti, G., Dwivedi, B., McDaniel, L. D., Varsani, A., Suttle, C. A., et al. (2011). Development of phoH as a novel signature gene for assessing marine phage diversity. Appl. Environ. Microbiol. 77, 7730-7739. doi: 10.1128/ AEM.05531-11

Hoang, D. T., Chernomor, O., von Haeseler, A., Minh, B. Q., and Vinh L. S. (2017). UFBoot2: improving the ultrafast bootstrap approximation. Mol. Biol. Evol. 35, 518-522. doi: 10.1093/molbev/msx281

Hofer, U. (2016). Viral Pathogenesis: Tracing the steps of Zika virus. Nat. Rev. Microbiol. 14:401. doi: 10.1038/nrmicro.2016.80

Hopkins, M., Kailasan, S., Cohen, A., Roux, S., Tucker, K. P., Shevenell, A., et al. (2014). Diversity of environmental single-stranded DNA phages revealed by PCR amplification of the partial major capsid protein. ISME J. 8, 2093-2103. doi: 10.1038 /ismej.2014.43

Horvath, P., and Barrangou, R. (2010). CRISPR/Cas, the immune system of bacteria and archaea. Science 327, 167-170. doi: 10.1126/science.117 9555

Hyatt, D., Chen, G. L., Locascio, P. F., Land, M. L., Larimer, F. W., and Hauser, L. J. (2010). Prodigal: prokaryotic gene recognition and translation initiation site identification. BMC Bioinformatics 11:119. doi: 10.1186/1471-210511-119

Jones, P., Binns, D., Chang, H. Y., Fraser, M., Li, W., McAnulla, C., et al. (2014). InterProScan 5: genome-scale protein function classification. Bioinformatics 30, 1236-1240. doi: 10.1093/bioinformatics/btu031

Jover, L. F., Effler, T. C., Buchan, A., Wilhelm, S. W., and Weitz, J. S. (2014). The elemental composition of virus particles: implications for marine biogeochemical cycles. Nat. Rev. Microbiol. 12, 519-528. doi: 10.1038/ nrmicro3289

Kanehisa, M., Sato, Y., and Morishima, K. (2016). BlastKOALA and GhostKOALA: KEGG tools for functional characterization of genome and metagenome sequences. J. Mol. Biol. 428, 726-731. doi: 10.1016/j.jmb.2015. 11.006

Kim, K. H., and Bae, J. W. (2011). Amplification methods bias metagenomic libraries of uncultured single-stranded and double-stranded DNA viruses. Appl. Environ. Microbiol. 77, 7663-7668. doi: 10.1128/AEM. 00289-11

Kraberger, S., Argüello-Astorga, G. R., Greenfield, L. G., Galilee, C., Law, D., Martin, D. P., et al. (2015). Characterisation of a diverse range of circular replication-associated protein encoding DNA viruses recovered from a sewage treatment oxidation pond. Infect. Genet. Evol. 31, 73-86. doi: 10.1016/j.meegid. 2015.01.001

Krupovic, M., and Forterre, P. (2011). Microviridae goes temperate: microvirusrelated proviruses reside in the genomes of Bacteroidetes. PLoS One 6:e19893. doi: 10.1371/journal.pone.0019893

Krupovic, M., Ghabrial, S. A., Jiang, D., and Varsani, A. (2016). Genomoviridae: a new family of widespread single-stranded DNA viruses. Arch. Virol. 161, 2633-2643. doi: 10.1007/s00705-016-2943-3

Letunic, I., and Bork, P. (2016). Interactive tree of life (iTOL) V3: an online tool for the display and annotation of phylogenetic and other trees. Nucleic Acids Res. 44, W242-W245. doi: 10.1093/nar/gkw290

Margulies, M., Egholm, M., Altman, W. E., Attiya, S., Bader, J., BembeN, L. A., et al. (2005). Genome sequencing in microfabricated high-density picolitre reactors. Nature 437, 376-380. doi: 10.1038/nature03959
Meyer, F. D., Paarmann, M., D’Souza, R., Olson, E. M., Glass, M., Kubal, T., et al. (2008). The metagenomics RAST server - A public resource for the automatic phylogenetic and functional analysis of metagenomes. BMC Bioinform. 9:386. doi: 10.1186/1471-2105-9-386

Ofir, G., Melamed, S., Sberro, H., Mukamel, Z., Silverman, S., Yaakov, G., et al. (2018). DISARM is a widespread bacterial defence system with broad antiphage activities. Nat. Microbiol. 3, 90-98. doi: 10.1038/s41564-017-0051-0

Okonechnikov, K., Golosova, O., Fursov, M., and Ugene team (2012). Unipro UGENE: a unified bioinformatics toolkit. Bioinformatics 28, 1166-1167. doi: 10.1093/bioinformatics/bts091

Paez-Espino, D., Eloe-Fadrosh, E. A., Pavlopoulos, G. A., Thomas, A. D., Huntermann, M., Mikhailova, N., et al. (2016). Uncovering Earth's virome. Nature 536, 425-430. doi: 10.1038/nature19094

Reyes, A., Haynes, M., Hanson, N., Angly, F. E., Heath, A. C., Rohwer, F., et al. (2010). Viruses in the faecal microbiota of monozygotic twins and their mothers. Nature 466, 334-338. doi: 10.1038/nature09199

Rosario, K., Duffy, S., and Breitbart, M. (2009a). Diverse circovirus-like genome architectures revealed by environmental metagenomics. J. Gen. Virol. 90, 2418-2424. doi: 10.1099/vir.0.012955-0

Rosario, K., Nilsson, C., Lim, Y. W., Ruan, Y., and Breibart, M. (2009b). Metagenomic analysis of viruses in reclaimed water. Environ. Microbiol. 11, 2806-2820. doi: 10.1111/j.1462-2920.2009.01964.x

Roux, S., Emerson, J. B., Eloe-Fadrosh, E. A., and Sullivan, M. B. (2017). Benchmarking viromics: an in silico evaluation of metagenome-enabled estimates of viral community composition and diversity. Peer J. 5:e3817. doi: $10.7717 /$ peerj.3817

Roux, S., Enault, F., Ravet, V., Pereira, O., and Sullivan, M. B. (2015). Genomic characteristics and environmental distributions of the uncultivated Far-T4 phages. Front. Microbiol. 6:199. doi: 10.3389/fmicb.2015.00199

Roux, S., Faubladier, M., Mahul, A., Paulhe, N., Bernard, A., Debroas, D., et al. (2011). Metavir: a web server dedicated to virome analysis. Bioinformatics 27, 3074-3075. doi: 10.1093/bioinformatics/btr519

Roux, S., Solonenko, N. E., Dang, V. T., Poulos, B. T., Schwenck, S. M., Goldsmith, D. B., et al. (2016). Towards quantitative viromics for both doublestranded and single-stranded DNA viruses. Peer J. 4:e2777. doi: 10.7717/peerj. 2777

Roux, S., Tournayre, J., Mahul, A., Debroas, D., and Enault, F. (2014). Metavir 2: new tools for viral metagenome comparison and assembled virome analysis. BMC Bioinform. 15:76. doi: 10.1186/1471-2105-15-76

Ruvindy, R., White, R. A. III, Neilan, B. A., and Burns, B. P. (2016). Unravelling core microbial metabolisms in the hypersaline microbialites of Shark Bay using high-throughput metagenomics. ISME. J. 10, 183-196. doi: 10.1038/ismej. 2015.87

Saccardo, F., Cettul, E., Palmano, S., Noris, E., and Firrao, G. (2011). On the alleged origin of geminiviruses from extrachromosomal DNAs of phytoplasmas. BMC Evol. Biol. 11:185. doi: 10.1186/1471-2148-11-185

Sambrook, J., Fritsch, E. F., and Maniatis, T. (1989). Molecular Cloning, 2nd Edn, Vol. 1. Cold Spring Harbor, NY: Cold Spring Harbor Laboratory Press.

Scanlan, D. J., and Wilson, W. H. (1999). Application of molecular techniques to addressing the role of $\mathrm{P}$ as a key effector in marine ecosystems. Hydrobiologia 401, 149-175. doi: 10.1007/978-94-011-4201-4_12

Schmieder, R., and Edwards, R. (2011). Quality control and preprocessing of metagenomic datasets. Bioinformatics 27, 863-864. doi: 10.1093/ bioinformatics/btr026

Schmieder, R., Lim, W. Y., Rohwer, R., and Edwards, R. (2010). TagCleaner: identification and removal of tag sequences from genomic and metagenomic datasets. BMC Bioinformat. 11:341. doi: 10.1186/1471-2105-11-341

Smith, S. V., and Atkinson, M. J. (1984). Phosphorus limitation of net production in a confined aquatic ecosystem. Nature 307, 626-627. doi: 10.1038/307 $626 a 0$

Sullivan, M. B., Weitz, J. S., and Wilhelm, S. (2017). Viral ecology comes of age. Environ. Microbiol. Rep. 9, 33-35. doi: 10.1111/1758-2229. 12504

Suosaari, E. P., Reid, R. P., Playford, P., Foster, J. S., Stolz, J. F., Casaburi, G., et al. (2016). New multi-scale perspectives on the stromatolites of Shark Bay. Western Australia. Sci. Rep. 6:20557. doi: 10.1038/srep20557

Suttle, C. A. (2005). Viruses in the sea. Nature 437, 356-361. doi: 10.1038/ nature 04160 
Suttle, C. A. (2007). Marine viruses - major players in the global ecosystem. Nat. Rev. Microbiol. 5, 801-812. doi: 10.1038/nrmicro1750

Szekely, A. J., and Breitbart, M. (2016). Single-stranded DNA phages: from early molecular biology tools to recent revolutions in environmental microbiology. FEMS Microbiol. Lett. 363:fnw027. doi: 10.1093/femsle/ fnw027

Thompson, L. R., Zeng, Q., Kelly, L., Huang, K. H., Singer, A. U., Stubbe, J., et al. (2011). Phage auxiliary metabolic genes and the redirection of cyanobacterial host carbon metabolism. Proc. Natl. Acad. Sci. U.S.A. 108, E757-E764. doi: $10.1073 /$ pnas. 1102164108

Thurber, R. V., Haynes, M., Breitbart, M., Wegley, L., and Rohwer, F. (2009). Laboratory procedures to generate viral metagenomes. Nat. Protoc. 4, 470-483. doi: $10.1038 /$ nprot.2009.10

Valdespino-Castillo, P. M., Alcántara-Hernández, R. J., Alcocer, J., MerinoIbarra, M., Macek, M., and Falcón, L. I. (2014). Alkaline phosphatases in microbialites and bacterioplankton from Alchichica soda lake, Mexico. FEMS Microbiol. Ecol. 90, 504-519. doi: 10.1111/1574-6941. 12411

Van Kranendonk, M. J., Philippot, P., Lepot, K., Bodrokos, S., and Piranjno, F. (2008). Geological setting of Earth's oldest fossils in the ca. 3.5 GA Dresser formation, Pilbara Craton, Western Australia. Precambrian Res. 167, 93-124. doi: 10.1016/j.precamres.2008.07.003

White, R. A. III, Bottos, E. M., Roy-Chowdhury, T., Zucker, J. D., Brislawn, C. J., Nicora, C. D., et al. (2016a). Moleculo long-read sequencing facilitates assembly and genomic binning from complex soil metagenomes. mSystems 1, e00045-16. doi: 10.1128/mSystems.00045-16

White, R. A. III, Chan, A. M., Gavelis, G. S., Leander, B. S., Brady, A. L., Slater, G. F., et al. (2016b). Metagenomic analysis suggests modern freshwater microbialites harbour a distinct core microbial community. Front. Microbiol. 6:1531. doi: $10.3389 /$ fmicb.2015.01531

White, R. A. III, Power, I. M., Dipple, G. M., Southam, G., and Suttle, C. A. (2015). Metagenomic analysis reveals that modern microbialites and polar microbial mats have similar taxonomic and functional potential. Front. Microbiol. 6:966. doi: $10.3389 /$ fmicb.2015.00966

Wong, H. L., Smith, D. L., Visscher, P. T., and Burns, B. P. (2015). Niche differentiation of bacterial communities at a millimeter scale in Shark Bay microbial mats. Sci. Rep. 5:15607. doi: 10.1038/srep15607

Wong, H. L., Visscher, P. T., White, R. A. III, Smith, D.-L., Patterson, M., and Burns, B. P. (2017). Dynamics of archaea at fine spatial scales in Shark Bay mat microbiomes. Sci. Rep. 7:46160. doi: 10.1038/srep46160

Zheng, Q., Zhang, R., Xu, Y., White, R. A. III., Wang, Y., Luo, T., et al. (2014). A marine inducible prophage vB_CibM-P1 isolated from the aerobic anoxygenic phototrophic bacterium citromicrobium bathyomarinum JL354. Sci. Rep. 4:7118. doi: 10.1038/srep07118

Conflict of Interest Statement: The authors declare that the research was conducted in the absence of any commercial or financial relationships that could be construed as a potential conflict of interest.

Copyright (C) 2018 White, Wong, Ruvindy, Neilan and Burns. This is an open-access article distributed under the terms of the Creative Commons Attribution License (CC BY). The use, distribution or reproduction in other forums is permitted, provided the original author(s) and the copyright owner are credited and that the original publication in this journal is cited, in accordance with accepted academic practice. No use, distribution or reproduction is permitted which does not comply with these terms. 